\title{
Engelhardt on the Family ${ }^{1}$
}

\author{
李翰林
}

In "The Family: Crucial to and Divisive in Bioethics," leading bioethicist and philosopher Tristram Engelhardt, Jr. offers erudite and compelling arguments for the Conservative $\mathrm{View}^{2}$ that the traditional family is an important good to people and that it has significant impact on society as well as on bioethics. On the other hand, he undermines the kind of Individualism ${ }^{3}$ prevalent in many societies today.

Personally, I would to a great extent ${ }^{4}$ endorse the Conservative View, and I would personally find it difficult to live with a partner who embraces the Individualist View. That said, I should not be responding to Engelhardt's thoughtful and inspiring paper, if all that matter were our personal self-regarding views.

When Obama was running for re-election in November 2012, vice-presidential candidate Paul Ryan and Vice-president Joe Biden had a debate. Responding to a question on abortion, Ryan said that being Irish and Catholic he would support laws to prohibit abortion. However, Biden responded that, though being Irish and Catholic he would personally be against abortion, he would not seek laws to ban abortion. Biden's view is nuanced and attractive. What he is relying on, if not explicitly spelled out, is the idea of public reason: Catholics have a religious, metaphysical and

\section{李翰林, 香港中文大學哲學系教授, 中國香港。}

《中外醫學哲學》XI:2 (2013 年) : 頁 153-160。

(C) Copyright 2013 by Global Scholarly Publications.

(1) I would like to thank Andrew Brennan, Yong Huang, Franz Mang, and especially Peter Chau for comments on the penultimate draft of this paper. I also thank the Editor for comments, and for allowing me not to accept some of his suggestions.

(2) Engelhardt calls this the "ontological or metaphysical" account of the family.

(3) I do not follow Engelhardt in labeling this view as the "Liberal-Libertarian account," if only because a liberal can endorse the Conservative View of the family. I think the main underlying spirit of this view is individualism.

(4) But see part III below. 
hence "nonpublic reason" 5 to be against abortion. Non-Catholics might have no such reasons to be against abortion. Thus, a Catholic's reason against abortion is largely ${ }^{6}$ a religious reason, something that cannot be shared by non-Catholics.

A public reason, on the other hand, does not rely on any religious, metaphysical, philosophical, or controversial doctrines. Because it does not rely on any controversial doctrine, it is "freestanding" ${ }^{7}$. Moreover, it is public and shareable because it is accessible by anyone who is reasonable.

Grounded on the idea of public reason, we should object to the state which employs material incentives or other means to entice people into having a traditional family on the grounds that this is part of a good life, or to discourage or penalize those seeking an individualist lifestyle. Although Engerhardt stops short of saying that the state should promote the idea of a traditional family by any of these means, "state perfectionists" who agree with his view on the family might make this point. It is therefore worth spelling out why the state should not do so.

According to Engelhardt, it is good for individuals as well as society that people get married in the traditional way, stay in marriage, have children, and let children be under the parents' authority, etc. On the other hand, he believes the following groups of people would live a less good life: people who do not get married, those who get married but later divorce, those who cohabit ${ }^{8}$ as well as perhaps those who get married but decide not to have children. Perhaps those who would like to have children but are unable to, as well as those (such as Kant) who practice celibacy, could be viewed as living a less good life. (Engelhardt also places emphasis on the fact that children born out of the wedlock are more likely to have problems of various kinds. ${ }^{9}$ But I do not have room here to discuss this later claim. Nor shall discuss various implications of the family on bioethics.)

(5) John Rawls, Political Liberalism (New York: Columbia University Press, 1993), p.220.

(6) I am not saying that a Catholic cannot be against abortion on a ground unconnected to Catholicism, as he or she may accept the view expressed in Don Marquis, "Why Abortion is Immoral,” Journal of Philosophy, vol. 86 (Apr 1989), pp.183-202. Nor am I saying that a non-Catholic cannot be against abortion. However, insofar as a Catholic believes that a fetus is a person because the Pope says so, his/her ground and the non-Catholic's ground against abortion would come from different sources.

(7) John Rawls, Political Liberalism.

(8) The line between marriage and cohabitation is now blurred because in a growing number of jurisdictions (e.g., England, USA) would consider cohabitation as a type of common-law marriage.

(9) See Note 8. 
The idea of public reason, ${ }^{10}$ according to John Rawls, is that the constitutional fundamentals and basic justice in a society can be decided by reference to political values that are independent of people's religious, metaphysical, and philosophical views, insofar as there is an "overlapping consensus" ${ }^{11}$ on these values. Thus, a law is legitimate if it can be justified to those who are in reasonable disagreement over the meaning of life, the kind of freedom that people should strive for, as well as what constitutes a good life, viz. what Rawls terms "comprehensive doctrines" ${ }^{12}$. This is because, Rawls thinks, matters of basic justice should not include values that are part of some reasonable comprehensive doctrines, but not others ${ }^{13}$.

Seen from the perspective of public reason, strategies by the state to reward those who have the traditional family, or to discourage or penalize those who practice the individualistic lifestyles would be unjust, since the disagreement over the family would seem to be reasonable. This is because the state would support values of some reasonable comprehensive doctrine, viz. the Conservative View, but not those of the Individualist View. It is also because if a state does so, it would be disrespectful of those who do not share the state's prescribed conception of what a good life is. ${ }^{14}$

(10) The idea of public reason was used earlier by Hobbes, Rosseau and Kant.

(11) John Rawls, Political Liberalism.

(12) John Rawls, Political Liberalism.

(13) John Rawls, Political Liberalism; T. M. Scanlon, "Rawls on Justification," in The Cambridge Companion to Rawls, Samuel Freeman, ed. (Cambridge: Cambridge University Press, 2003); Burton Dreben, “On Rawls and Political Liberalism," in The Cambridge Companion to Rawls, Samuel Freeman, ed. (Cambridge: Cambridge University Press, 2003); Samuel Freeman, Rawls (Oxon, UK \& New York: Routledge, 2007).

(14) Jonathan Quong, "Public Reason," The Stanford Encyclopedia of Philosophy (Summer 2013 Edition), Edward N. Zalta ed., retrieved on 10 September, 2013:

http://plato.stanford.edu/archives/sum2013/entries/public-reason/;

Joseph Raz, "Disagreement in Politics," The American Journal of Jurisprudence: An International Forum for Legal Philosophy 43 (1998), pp.25-52; Steven Wall, "Perfectionism in Moral and Political Philosophy," The Stanford Encyclopedia of Philosophy (Summer 2013 Edition), Edward N. Zalta ed., retrieved on 10 September, 2013: http://plato.stanford.edu/archives/sum2013/entries/perfectionism-moral/. Raz argues that if we disagree with some people's (mistaken) conception of good life, we do not necessarily disrespect them. However, from the perspective of public reason, the disagreement in question here is ex hypothesi "reasonable" (John Rawls, Political Liberalism). Consider this analogy: You invite friends to your home for dinner. Knowing that although some friends love spicy food whereas others do not like them, almost all dishes you cooked are quite spicy. Might your friends who dislike spicy food feel slighted, at least, and even disrespected especially if you try to persuade them that spicy food is good for them? 


\section{II}

Engelhardt believes that the traditional family is a structure "that all families should try to realize." ${ }^{15}$ Let us now turn to the question whether having a traditional family is a good to everyone, and whether those who have decided not to have a traditional family could be persuaded otherwise.

If the traditional family is a good that all families should try to realize, then it is a universal good, that is, a good that can be justified to people with different nature, ability, need, preferences, disposition, or perspectives. For instance, if having a traditional family were a universal good, it would be justifiable not only to people who want to get married and stay in the marriage and have children, but also to the following categories of people: (1) those who need to divorce, (2) spouses who do not intend to have children because they have careers or projects, or simply because they prefer not to be burdened with the onerous burden of raising children, (3) those who practice celibacy, (4) heterosexuals who prefer to have a free lifestyle, ${ }^{16}(5)$ homosexuals, (6) lesbians, (7) those who biologically cannot have children, (8) those who financially cannot afford to have children. Can the idea that having a traditional family is a good be justified to these eight categories of people? The answer is: Surely not all of them.

Suppose you like classical music, but you cannot play any instrument. While you enjoy listening to classical music, you cannot take part in or appreciate classical music the way that a pianist or a violinist can. Nevertheless, classical music is a good to you. This would be very roughly analogous to the case where someone who cannot or do not have children, but nevertheless enjoys the traditional family, if vicariously: When she visits her brother's family, she enjoys playing with his children. If Engelhardt is successful, he may be able to persuade some who would have opted not to have any children, or not to get married, to rethink the whole idea. $^{17}$

Now suppose someone tells you that heavy rock music or Cantonese Opera is terrific, whereas you hate it so much that you would get a

(15) Engelhardt raises the question: "Is there a structure that all families should try to realize, or is it the case that humans can structure the family as they wish without important social and moral costs?” It is clear that he thinks that there is a structure, viz. the traditional family, that all families should try to realize.

(16) These include people who get married after divorce, those who prefer to engage serial monogamy, as well as those who live a promiscuous sexual life.

(17) However, I am not optimistic. For one thing, the kind of arguments Engelhardt advances mainly appeal to consequences, rather than the intrinsic good of having children. If he says more about the intrinsic good of having children, he may be more successful in persuading those who have decided not to have children. 
headache after listening to it for more than a minute. This is analogous to a case where someone who simply dislikes children. In this case, having a traditional family is not an intrinsic good to you at all.

Next suppose you don't dislike heavy rock or Cantonese Opera, but you cannot possibly afford the costs of attending a concert featuring heavy rock or Cantonese Opera. This would be analogous to the case where someone who abhors the idea of having to bear or bring up a child, or to sacrifice her cherished career, or to give it up for some altruistic concern that clashes with having a traditional family (e.g., she works for Médecins Sans Frontières). In this case, having a traditional family is everything considered not a good to her.

Therefore, while there are many people lucky enough to have a compatible spouse and be able to raise happy children, this does not show that having a traditional family is a universal good. ${ }^{18}$ Nor is it easy to persuade those who have decided not to have children to form traditional families. ${ }^{19}$

\section{III}

While I personally and rather unreflectively agree with Engelhardt's idea of the traditional family (since I myself have a traditional family), let me step back from this vantage point and reflect on this idea from a more detached standpoint. According to Engelhardt, the traditional family is grounded on certain traditional values, such as the norm that parents have authority over children. Moreover, he claims that the family cannot be reduced into individual members but must be regarded as a whole, and that individual needs are subordinated to the need of the family. ${ }^{20}$ Finally, he is against the "egalitarian aspirations" of liberalism.

I assume that ideally members in a family should be analogous to members in a jazz band in that each would perform his or her individual task, but all together would coordinate in the larger enterprise, so that the

(18) While certain conceptions of the good might be uncontroversially seen to be superior to other conceptions, when a comparison is carried out locally (Joseph Chan 陳祖為, "Legitimacy, Unanimity, and Perfectionism," Philosophy and Public Affairs, 29:1 (Winter 2000), pp.13-14), the issue of the family is not uncontroversial.

(19) The point is that in order for moral prescriptions to make sense, we must consider the perspectives of those whom the prescription is addressed, or else such prescription would not make sense from their perspectives. For an account of this idea, viz. how public reason is applicable to social morality, see Gerald F. Gaus, The Order of Public Reason: A Theory of Freedom and Morality in a Diverse and Bounded World (New York: Cambridge University Press, 2011), pp.205-232, esp.184.

(20) I infer this from Engelhardt's disapproval of the following: “... there is an accent on the pursuit of individual self-fulfillment in preference to the flourishing of the family as a whole." 
whole is greater - and richer - than the sum of its parts. ${ }^{21}$ In this analogy each individual's development is flourishingly realized while the whole is also promoted and enhanced.

How close is the traditional family to this admittedly ideal conception? If we look more closely into the traditional family as it is, we see that in both China and America, too often the career of the wife is sacrificed in order to take care of the family, even should she hold an advanced degree from a prestigious university or a professional qualification in accountancy, law, or medicine. On the other hand, one rarely sees the reverse, where the man sacrifices his career so that his wife can flourish in hers.

According to research conducted by Plagnol and Easterlin, "[w]omen end up less happy than men," because in later life it is "men who come closer to fulfilling their aspirations, are more satisfied with their family lives and financial situations, and are the happier of the two." ${ }^{22}$ In another study, it is shown that "[w]omen [are] happier than men after divorce." ${ }^{23}$ Finally, the National Marriage Project at Rutgers found that two-thirds of all divorces are initiated by women. ${ }^{24}$ The findings in these studies corroborate with each other to form the picture that women are generally less happy than men after marriage, and therefore that they (more than men) are more inclined toward initiating a divorce. What accounts for this phenomenon? The obvious explanation is that more women have sacrificed their possible career for the family, whereas more men flourish in having a traditional family where their wives take care of the children and (almost) everything else. ${ }^{25}$ It is true that, like any other theory in this area, this explanation is conjectural, but it is one that is too uncomfortable to ignore.

(21) I take this analogy of the jazz band from G. A. Cohen, Karl Marx's Theory of History: A Defence (Princeton, NJ: Princeton University Press, 1978), where he argues that members of a classless society should be like members in a jazz band.

(22) For details, see Anke C. Plagnol \& Richard A. Easterlin, "Aspirations, Attainments, and Satisfaction: Life Cycle Differences Between American Women and Men,” Journal of Happiness Studies, 9:4 (Dec 2008), pp. 601, 613-615.

(23) See Andrew E. Clark \& Yannis Georgellis, "Back to Baseline in Britain: Adaptation in the British Household Panel Survey,” Economica, 80:319 (2013), pp. 504-505; Or see Theresa Boyle (Toronto Star Newspaper Ltd.) reported, "Women happier than men after divorce, study finds", retrieved on 10 September, 2013:

http://www.thestar.com/life/2013/07/11/marital_split_women_happier_after_divorce study.html.

(24) David Popenoe and Barbara Dafoe Whitehead, "The Top Ten Myths of Divorce (Information brief)," from the National Marriage Project's Ten Things to Know Series (Apr 2001), available at: http://nationalmarriageweekusa.net/images/research/MythsDivorce.pdf.

(25) See Note 24 for the study that supports this conclusion. 
On Rawls' view, the family is part of the basic structure, and there should be "equality of opportunity" for both genders ${ }^{26}$. That such equality does not obtain is too obvious, as "a long and historic injustice to women is that they have borne, and continue to bear, a disproportionate share of the task of raising, nurturing and caring for their children". ${ }^{27}$

More than three decades ago, Thomas Nagel said to me from nowhere ${ }^{28}$ and without further explanation: "The greatest injustice happens within the family." I did not ask for further explanation, but I have been left puzzled since then as to what he really meant and why he said it. I think I may be beginning to see what he had in mind.

\section{參考文獻}

Engelhardt, Jr., H. Tristram. "The Family: Crucial to and Divisive in Bioethics," International Journal of Chinese \& Comparative Philosophy of Medicine, 11:2 (2013), pp.113-127.

Boyle, Theresa (Toronto Star Newspaper Ltd.) reported. "Women Happier than Men after Divorce, Study Finds”, retrieved on 10 September, 2013:

http://www.thestar.com/life/2013/07/11/marital_split_women_happier_aft er_divorce_study.html.

Chan, Joseph (陳祖為). “Legitimacy, Unanimity, and Perfectionism,” Philosophy and Public Affairs, 29:1 (Winter 2000), pp.5-42.

Clark, Andrew E. \& Yannis Georgellis. "Back to Baseline in Britain: Adaptation in the British Household Panel Survey,” Economica, 80:319 (2013), pp. 496-512.

Cohen, Gerald Allan. Karl Marx's Theory of History: A Defence (Princeton, NJ: Princeton University Press, 1978).

Dreben, Burton. "On Rawls and Political Liberalism," in The Cambridge Companion to Rawls, Samuel Freeman, ed. (Cambridge: Cambridge University Press, 2003).

Freeman, Samuel. Rawls (Oxon, UK \& New York: Routledge, 2007).

Gaus, Gerald F. The Order of Public Reason: A Theory of Freedom and Morality in a Diverse and Bounded World (New York: Cambridge University Press, 2011).

Marquis, Don. "Why Abortion is Immoral," Journal of Philosophy, vol. 86 (Apr 1989), pp.183-202.

(26) John Rawls, Justice as Fairness: A Restatement (Cambridge, Mass.: Harvard University Press, 2001), p.163.

(27) John Rawls, Justice as Fairness: A Restatement, p.166. See also John Rawls, The Law of Peoples (Cambridge, Mass.: Harvard University Press, 1999), pp.158-161. Okin points out that nearly all prominent theories of justice have ignored gender injustice. She regards the family as the linchpin of gender injustice. See Susan Moller Okin, Justice, Gender, and the Family (New York: Basic Books, Inc., 1991).

(28) At the time, Nagel supervised me to write my Junior Paper on distributive justice at Princeton University. But what he said was not really connected to what we were discussing. That is why I said "from nowhere." 
Okin, Susan Moller. Justice, Gender, and the Family (New York: Basic Books, Inc., 1991).

Plagnol, Anke C. \& Richard A. Easterlin. "Aspirations, Attainments, and Satisfaction: Life Cycle Differences Between American Women and Men,” Journal of Happiness Studies, 9:4 (Dec 2008), pp. 601-619.

Popenoe ,David \& Barbara Dafoe Whitehead. “The Top Ten Myths of Divorce (Information brief)", from the National Marriage Project's Ten Things to Know Series (Apr 2001). Available at:

http://nationalmarriageweekusa.net/images/research/MythsDivorce.pdf.

Quong, Jonathan. "Public Reason," The Stanford Encyclopedia of Philosophy (Summer 2013 Edition), Edward N. Zalta ed. Retrieved on 10 September, 2013: http://plato.stanford.edu/archives/sum2013/entries/public-reason/.

Rawls, John. Political Liberalism (New York: Columbia University Press, 1993).

Rawls, John. The Law of Peoples (Cambridge, Mass.: Harvard University Press, 1999).

Rawls, John. Justice as Fairness: A Restatement (Cambridge, Mass.: Harvard University Press, 2001).

Raz, Joseph. “Disagreement in Politics,” The American Journal of Jurisprudence: An International Forum for Legal Philosophy, 43 (1998), pp.25-52.

Scanlon, T. M. "Rawls on Justification," in The Cambridge Companion to Rawls, Samuel Freeman, ed. (Cambridge: Cambridge University Press, 2003).

Wall, Steven. "Perfectionism in Moral and Political Philosophy," The Stanford Encyclopedia of Philosophy (Summer 2013 Edition), Edward N. Zalta ed. Retrieved on 10 September, 2013:

http://plato.stanford.edu/archives/sum2013/entries/perfectionism-moral/. 